\title{
ANALISIS HUKUM ISLAM TERHADAP POLA KEMITRAAN USAHA PETERNAKAN AYAM POTONG DI PANCA RIJANG SIDRAP
}

\author{
Masluha \\ IAIN Parepare \\ abdulhamidsaja@gmail.com \\ Abdul Hamid \\ IAIN Parepare \\ Aris \\ IAIN Parepare
}

\begin{abstract}
Partnership Pattern is a partnership or what is known as syirkah, which is a collaboration between two parties, namely between the Company (Core) and breeders (Plasma). Through this partnership, both parties benefit, the farmers get capital while the company benefits from marketing livestock production and production facilities. The partnership pattern between PT. Ciomas Adistwa with breeders in the poultry farm business in Panca Rijang Sidrap revealed: first, the company facilitated the needs of farmers in terms of availability of production facilities and livestock products, while breeders prepared land, cages and cage equipment in the form of eating places, drinking places, and labor. Second, the contract between PT.Ciomas Adisatwa and the breeders in Panca Rijang Sidrap made a contract in accordance with an agreement agreed between each party. Third, the view of the Islamic economy towards the implementation of the business of broiler breeders in Panca Rijang Sidrap with the company PT.Ciomas Adisatwa, namely in terms of generating profits which are permitted according to Islam with the principle of mutual help to help in the good.
\end{abstract}

\section{Keywords: Partnership Pattern, Agreement Contract, Islamic Economics}

\begin{abstract}
Abstrak: Pola Kemitraan adalah kerjasama kemitraan atau yang dikenal sebagai syirkah yaitu kerjasama antara dua pihak yakni antara Perusahaan (Inti) dan peternak (Plasma). Melalui pola kemitraan ini, kedua belah pihak mendapatkan keuntungan, pihak peternak mendapatkan permodalan sedangkan perusahaan mendapatkan keuntungan dari memasarkan hasil produksi dan sarana produksi peternakan. Pola kemitraan antara PT. Ciomas Adistwa dengan peternak dalam usaha peternakan ayam potong di Panca Rijang Sidrap mengunkapakan: pertama, perusahaan memfasilitasi kebutuhan peternak dalam hal ketersediaan sarana produksi dan hasil ternaknya, sedangkan peternak menyiapkan lahan, kandang serta peralatan kandang berupa tempat makan, tempat minum, dan tenaga kerja. Kedua, kontrak perjanjian antara perusahaan PT.Ciomas Adisatwa dengan peternak di Panca Rijang Sidrap melakukan kontrak perjanjian yang sesuai kesepakatan yang telah disepakati dari masing-masing pihak. Ketiga, pandangan ekonomi Islam terhadap pelaksanaan usaha peternak ayam potong di Panca
\end{abstract}


Abdul Hamid dan Aris:

Analisis Hukum Islam Terhadap Pola Kemitraan Usaha Peternakan Ayam Potong di Panca Rijang Sidrap

Rijang Sidrap dengan perusahaan PT.Ciomas Adisatwa yaitu dalam hal menghasilkan keuntungan yang dibolehkan menurut Islam dengan prinsip saling tolong menolong dalam kebaikan.

Kata Kunci: Pola Kemitraan, Kontrak Perjanjian, Ekonomi Islam

\section{PENDAHULUAN}

Pemenuhan kebutuhan komsumsi masyarakat terhadap protein hewani yang bersumber dari ternak yang bernilai gizi tinggi memiliki peran penting dalam pembangunan sub sektor peternakan. Peternakan unggas atau ayam potong sebagai sumber protein hewani yang berasal dari peternakan ayam mempunyai potensi yang sangat besar. ${ }^{1}$ Berdasarkan data survei sosial ekonomi nasional, menunjukkan bahwa komsumsi daging ayam pedaging perkapita mengalami peningkatan setiap tahunya dengan tingkat pertumbuhan mencapai $4,6 \%$ pertahun. Masyarakat memiliki kecenderungan lebih banyak terhadap konsumsi daging ayam. Hal ini disebabkan karena harga daging ayam lebih murah dibandingkan dengan harga daging sapi, daging kerbau atau daging kambing perkilonya. Disamping itu, daging ayam lebih mudah diperoleh disebabkan karena jalur distribusinya pada pengecer yang langsung mendistribusikan pada konsumen akhir. Data dalam peternakan menunjukkan bahwa terjadi pertumbuhan produksi daging ayam sebesar $4,47 \%$ pada tahun $2012-2013 .^{2}$

Kerjasama dalam bentuk kemitraan dalam jangka waktu tertentu yang dilakukan oleh dua pihak atau lebih guna memperoleh keuntungan secara bersama-sama yang didasarkan pada prinsip saling menguntungkan, saling membutuhkan serta saling menguatkan. Kemitraan adalah salah satu strategi bisnis yang dilaksanakan oleh para pihak supaya saling menguatkan dengan mengedepankan tanggungjawab dan etika dalam berbisnis. Pada dasarnya kerjasama atau kemitraan muncul secara alamiah, tanpa ada paksaan, kemitraan semestinya lahir dari sebuah kesadaran untuk saling memahami, saling membutuhkan, saling melengkapi, dan saling percaya. Kemitraan bertujuan untuk mewujudkan profit sustrirability, yaitu antara mitra berdasarkan pada risk and 
Abdul Hamid dan Aris:

Analisis Hukum Islam Terhadap Pola Kemitraan Usaha Peternakan Ayam Potong di Panca Rijang Sidrap

profit sharing, serta perlu pada birokrasi yang baik, bersih dan beribawa dan penegakan hukum.

Bentuk kerjasama antara perusahaan dengan peternak adalah perusahaan sebagai inti memfasilitasi kredit modal usaha berupa sarana produksi peternakan serta membeli hasil produksi dengan harga yang telah disepakati dalam kontrak. ${ }^{3}$ Peternak sebagai plasma yang menyiapkan kandang beserta peralatan kandang, dan tenaga kerja dan harus memperoleh bimbingan secara rutin dari perusahaan terkait pengelolaan peternakan ayam.

Sarana-sarana produksi peternakan yang membutuhkan biaya yang besar serta jaminan harga jual ayam akan diperoleh oleh peternak melalui program kemitraan. Banyaknya kendala yang dihadapi dalam peternakan ayam terkait dengan sarana produksi maupun hasil produksi mengakibatkan persentase peternakan ayam secara mandiri berkurang dan lebih memilih bermitra dengan perusahan. Usaha ayam didominasi oleh usaha kemitraan yang mencapai angka 40-50\%, yang sebelumnya pangsapasarnya hanya 25-30\%.

Para peternak ayam potong di Panca Rijang Sidrap yang tergabung dalam perusahaan (PT.Ciomas Adisatwa) tidak diperbolehkan menjual hasil produksinya dalam hal ini ayam kepada pihak lain. PT.Ciomas Adisatwa membeli ayam peternak berdasarkan harga yang telah ditentukan sebelumnya dalam kontrak perjanjian. Para peternak akan mendapatkan keuntungan apabila dalam pemeliharaanya itu dapat dipelihara dengan baik sesuai dengan ketentuan dari pihak perusahaan. Selain itu, keuntungan peternak stabil disebabkan harga tidak terpengaruh dengan harga pasar karena harga sudah ditetapkan dalam kontrak.

PT.Ciomas Adisatwa banyak memberikan banyak keuntungan bagi usaha peternakan ayam potong di Panca Rijang Sidrap. Para peternak dapat menjalankan usahanya secara berkeseimbangan karena faktor modal yang sering menjadi kendala bagi peternak tidak lagi menjadi masalah.

Tulisan ini akan mengungkapkan tentang pelaksanaan pola kemitraan yang dilakukan oleh perusahaan (PT.Ciomas Adisatwa) dalam usaha peternakan ayam potong di Panca Rijang Sidrap serta bagaimana pola kemitraan tersebut dalam perspektif hukum Islam. 
Abdul Hamid dan Aris:

Analisis Hukum Islam Terhadap Pola Kemitraan Usaha Peternakan

Ayam Potong di Panca Rijang Sidrap

\section{PEMBahaSAN}

\section{A. Konsep Kemitraan dalam Islam}

Menurut Thoby Mutis Kemitraan ialah sebuah strategi bisnis yang dilaksanak oleh dua pihak atau beberapa pihak dalam jangka waktu tertentu untuk memperoleh manfaat bersama ataupun keuntungan bersama yang didasarkan pada prinsip saling membutuhkan dan saling mengisi sesuai kesepakatan yang muncul. ${ }^{4}$ Keinginan keduabelah pihak untuk menjalin suatu kerja sama dimaksudkan untuk memenuhi kebutuhan usaha antara satu dengan yang lainnya. Muhammad Jafar Hafsah menjelaskan bahwa kemitraan merupakan sebuah strategi bisnis yang dilaksanakan oleh dua atau beberpa pihak dalam jangka waktu tertentu guna ,e,peroleh keuntungan secara bersama-sama yang didasarkan pada prinsip saling membutuhkan dan membesarkan. ${ }^{5}$

Menurut bahasa mitra berarti teman, rekan, kawan dan pasangan kerja. Kemitraan berarti hubungan ataukah jalinan kerjasama selaku mitra. ${ }^{6}$ Secara esensial kemitraan dalam masyarakat lebih dikenal dengan sebutm gotong royong. Undang-Undang Republik Indonesia No.9 Tahun 1995 menyebutkan bahwa kemitraan merupakan kerjasama usaha antara usaha kecil dan usaha menengah atau usaha besar disertai pembinaan dan pengembangan oleh usaha menengah atau usaha besar tersebut dengan memperhatikan prinsip saling memerlukan, saling memperkuat dan saling menguntungkan. ${ }^{7}$

Kemitraan disebut musyarakah dalam kajian ekonomi Islam. Kata musyarakah berasal dari kata syirkah yang berarti al-ikhtilath (campur atau percampuran). ${ }^{8}$ Percampuran yang dimaksudkan adalah bercampurnya harta seseorang dengan harta orang lain sehingga tidak bisa membedakannya. Istilah musyarakah sering digunakan dalam konteks skim pembiayaan syarikah. Istilah musyarakah berkonotasi lebih terbatas daripada syirkah yang lebih umum digunakan dalam fiqih Islam. Musyarakah adalah akad kerjasama untuk mendapatkan keuntungan dengan cara penyatuan dan percampuran modal di antara mereka. Pihak-pihak yang bekerjasama membagi pengelolaan usaha berdasarkan kesepakatan. 
Abdul Hamid dan Aris:

Analisis Hukum Islam Terhadap Pola Kemitraan Usaha Peternakan Ayam Potong di Panca Rijang Sidrap

Musyarakah atau syirkah menurut Islam merupakan bentuk umum dari usaha bagi hasil antara dua atau beberapa orang. Keuntungan dibagi didasarkan pada kesepakatan antara para mitra, dan kerugian juga akan dibagikan berdasar pada proporsi modal. Transaksi musyarakah didasarkan pada pihak-pihak yang ingin bekerjasama guna peningkatan nilai aset yang dimiliki secara bersama dengan mengerahkan semua sumber daya yang dimiliki. ${ }^{9}$ Dalam musyarkah prinsip dasar yang dikembangkan adalah kerjasama atau kemitraan antara para pihak yang ingin mendapatkan kemajuan secara bersama

Macam-macam musyarakah dalam Islam adalah pertama, syirkah al'ina $>n$ yaitu kontrak kerjasama antara dua pihak atau lebih dimana para pihak memberikan suatu porsi dari seluruh dana dan ikut berpartisipasi dalam pekerjaan. ${ }^{10}$ Keuntungan dan kerugian dibagi oleh para pihak secara sama berdasarkan kesepakatan. Dalam syirkah porsi para pihak baik dalam pendanaan maupun dalam pekerjaan tidak mesti sama, akan tetapi didasarkan pada kesepakatan.

Kedua,Syirkah al-mufawadhah yaitu kontrak kerjasama antara dua pihak atau lebih dimana setiap pihak memberikan suatu porsi dari keseluruhan dana dan ikut dalam pekerjaan. Keuntungan dan kerugian dibagi oleh para pihak sesuai kesepakatan. Oleh karena itu, syarat utama dari syirkah ini ialah adanya dana yang sama, tanggung jawab, laba maupun kerugian. Berikutnya adalah syirkah al$a ' m a>l$, yaitu kontrak kerjasama yang dilakukan oleh dua pihak atau lebih yang seprofesi guna memperoleh pekerjaan secara bersamasama dan berbagi keuntungannya secara bersama pula. Selanjutnya syirkah al-wuju>h, yaitu kontrak kerjasama antara dua pihak atau lebih yang mempunyai reputasi dan prestis yang baik serta ahli dalam bisnis, dan yang terakhir adalah syirkah almudharabah yaitu kontrak kerjasama antara dua pihak atau lebih. Pihak pertama menyiapkan permodalan sedangkan pihak yang lain menyiapkan keterampilan kerja.

\section{B. Pola Kemitraan Usaha Peternakan Ayam Potong di Panca Rijang Sidrap}


Abdul Hamid dan Aris:

Analisis Hukum Islam Terhadap Pola Kemitraan Usaha Peternakan Ayam Potong di Panca Rijang Sidrap

Undang-Undang Nomor 9 Tahun 1995 menyebutkan bahwa kemitraan adalah kerjasama usaha kecil dengan usaha menengah atau dengan usaha besar disertai pembinaan dan pengembangan oleh usaha menengah atau usaha besar dengan memperhatikan prinsip saling memerlukan, saling memperkuat, dan saling menguntungkan, ini merupakan suatu landasan pengembangan usaha. Kerjasama merupakan bentuk usaha atau kegiatan dua pihak atau lebih guna memperoleh hasil yang lebih baik dibandingkan kalau perkerjaan tersebut dilakukan secara individual. Kerja sama ini merupakan kerjasama perjanjian antara para mitra usaha yang terdiri dari dua orang yakni antara pihak perusahaan (Inti) dan peternak (Plasma). Seperti halnya dalam pelaksanaan kontrak perjanjian pola kemitraan PT. Ciomas Adisatwa dengan usaha peternak ayam potong di Panca Rijang Sidrap yang melakukan kerjasama yang didasarkan pada kesepakatan kontrak.

Pelaksanaan kerjasama antara perusahaan dan peternak terdapat beberapa unsur di antaranya adanya akad kerjasama dan adanya modal. Pelaksanaan ternak ayam potong adalah usaha kerjasama yang dilakukan oleh dua pihak dimana kerjasama ini merupakan kerjasama perjanjian antara para mitra usaha yang terdiri dari dua pihak yakni pihak perusahaan (inti) dan peternak (plasma). Dalam pelaksanaan kerjasama tersebut diharapkan antara kedua belah pihak yang bekerja sama selalu melaksanakan kerjasama sesuai dengan kesepakatan perjanjian dalam kerjasama.

Praktik kerjasama antara perusahaan (PT.Ciomas Adisatwa) dengan peternak di Panca Rijang Sidrap ada dua pihak yakni pihak pertama perusahaan PT.Ciomas Adisatwa sedangkan pihak kedua yang ada di Panca Rijang Sidrap. Dalam hal ini pihak pertama menyediakan berupa sarana produksi di antaranya bibit ayam (DOC), pakan, obat-obatan serta keperluan lain peternak, adapun pihak kedua menyediakan lahan, peralatan kandang seperti tempat makan, tempat minum dan pemanas serta tenaga kerja.

Kesepakatan kontrak perjanjian antara pihak perusahaan PT. Ciomas Adistawa dengan peternak di Panca Rijang Sidrap dituangkan dalam kontrak tertulis dan disepakati oleh para pihak diawal kontrak serta ditandatangani oleh 
Abdul Hamid dan Aris:

Analisis Hukum Islam Terhadap Pola Kemitraan Usaha Peternakan Ayam Potong di Panca Rijang Sidrap

kedua belah pihak, dalam hal ini pihak peternak mengetahui lebih awal isi kontraknya sebelum pelaksanaa kerjasama tersebut terjalin dengan persetujuan dari pihak perusahaan. Dalam kontrak perjanjian tersebut ada beberapa persyaratan yang terkait dengan ketentuan yang perlu dipenuhi atau dilaksanakan oleh kedua belah pihak. PT. Ciomas Adisatwa memberi kepercayaan penuh kepada pihak peternak di Panca Rijang Sidrap dengan dasar kontrak kesepakatan. $^{11}$

Secara teoritis syarat yang dilakukan peternak untuk bergabung dalam anggota perusahaan PT.Ciomas Adisatwa dan kesepakatan lainya adalah sebagai berikut:

1. Setiap calon peternak yang ingin melakukan kerjasama dengan PT. Ciomas Adisatwa harus mengikuti ketentuan-ketentuan yang diberlakukan oleh PT.Ciomas Adisatwa.

2. Semua calon peternak yang mengingnkan kerjasama dalam bidang peternakan ayam potong wajib mempunyai kandang yang layak untuk ditempati (kandang panggung) dan keperluan yang dibutuhkan lainnya sesuai dengan standar yang berlaku seperti tempat makan, tempat minum, pemanas dsb.

3. Setiap calon peternak yang menginginkan kerjasama pengembangbiakan ayam potong dengan PT. Ciomas Adisatwa wajib menyiapkan uang jaminan sesuai dengan tingkat usaha dan menyerahkannya sesuai kesepakatan. Uang jaminan tersebut disimpan oleh pihak PT. Ciomas Adisatwa sebagai pegangan/jaminan dalam keberlangsungan kerjasama antara para pihak, dalam hal ini dilaksanakan oleh pihak PT. Ciomas Adisatwa untuk meminimalkan kerugian dengan adanya uang jaminan tersebut.

4. Tempat atau kandang dan keperluan kandang harus sesuai dengan standar yang berlaku harus dipastikan dan dijamin oleh peternak sebelum bibit ayam dimasukkan atau dikembangbiakkan.

5. Observasi akan dilakukan oleh pihak perusahaan untuk melihat secara lansung kelayakan sebelum mengirimkan bibit ayam (DOC), makanan, obat- 
$\mathcal{A} 6$ du $\mathcal{H}$ Hamid dan Arís:

Analisis Hukum Islam Terhadap Pola Kemitraan Usaha Peternakan Ayam Potong di Panca Rijang Sidrap

obatan, vaksin dan kebutuhan ayam lainnya sesuai dengan perjanjian yang berlaku.

6. Peternak wajib melaporkan perkembangan peternakan yang dikelolanya kepada PT. Ciomas Adisatwa.

7. Kedua belah pihak akan menanggung kerugian secara bersama jika misalnya ayam tersebut mati karena terkena penyakit, maka pihak peternak meskipun ayam potong tersebut mengalami kematian yang banyak maka tidak diwajibkan untuk mengganti kerugian kepada pihak PT. Ciomas Adisatwa.

Kerjasama kemitraan yang dilakukan antara PT. Ciomas Adisatwa dengan peternak ayam potong di Panca Rijang Sidrap ini dilakukan antara dua pihak yang bekerjasama yaitu pihak perusahaan dengan peternak. Dalam pelaksanaan usaha tersebut yang paling banyak bekerja atau berperan aktif yakni pihak peternak plasma sedangkan pihak perusahaan hanya berperan dalam pengawasan dan pengarahan. Hal ini sebagaimana yang diungkapkan oleh pimpinan PT.Ciomas Adisatwa bahwa untuk bergabung dalam perusahaan PT.Ciomas Adisatwa ada beberapa syarat yang harus disiapkan peternak di antaranya, ada lahan yang biasa juga disebut persiapan kandang, modal yaitu menyiapkan semua peralatan kandang termasuk tempat makan, tempat air minum serta siap dengan alat pemanas dan ada tenaga kerja yang siap untuk berternak. Perusahaan sebagai pengawas manajemen pemeliharaan karena adanya target tersendiri dari pihak perusahaan yang dibebankan kepada peternak dari pemeliharaan ayam tersebut. ${ }^{12}$

Kemitraan yang dilaksanakan oleh perusahaan PT. Ciomas Adisatwa dengan peternak menimbulkan adanya hak dan kewajiban bagi para pihak yang terlibat dalam perjanjian kemitraan peternak di Panca Rijang Sidrap. Kewajiban tersebut berdasar pada kontrak kesepakatan perjanjian yang telah disetujui dan ditanda tangani oleh pihak peternak dengan pihak perusahaan sebelum berproduksi. Hal ini sebagaimana yang dikatakan oleh pimpinan kepala unit Kantor PT.Ciomas Adistwa sebagai berikut

Adapun kewajiban dari pihak Perusahaan PT.Ciomas Adisatwa: ${ }^{13}$

1. Pihak perusahaan wajib menyediakan sarana produksi ternak berupa bibit ayam (DOC), pakan ternak, vaksin dan obat-obatan. 
Abdul Hamid dan Aris:

Analisis Hukum Islam Terhadap Pola Kemitraan Usaha Peternakan Ayam Potong di Panca Rijang Sidrap

2. Pihak perusahaan wajib membeli semua hasil produksi dari peternak apabila waktu panen tiba.

3. Pihak perusahaan wajib memberikan bimbingan kepada peternak apabila ada kesulitan yang timbul dalam proses pemeliharaan berlangsung.

Adapun kewajiban dari pihak peternak:

1. Pihak peternak wajib menyediakan kandang yang layak ditempati untuk berternak serta peralatan yang diperlukan seperti pemanas, tempat makan dan tempat minum.

2. Pihak peternak wajib menjual hasil produksinya kepada pihak perusahaan.

Usaha peternakan ayam potong di Panca Rijang Sidrap berdasarkan hasil penelitian belum sepenuhnya berjalan secara efektif atau bisa dikatakan bahwa tingkat keberhasilan peternak belum mencapai seratus persen. Hal tersebut terjadi karena adanya kendala yang tidak dapat diatasi secara optimal seperti halnya dengan gagal panen dalam satu periode dapat mengalami kerugia atau disebabkan kendala cuaca yang berpengaruh terhadap kualitas dan kuantitas hasil produksi ataukah terpengaruh oleh biaya produksi

\section{Pola Kemitraan Usaha Peternakan Ayam Potong di Panca Rijang Sidrap Perspektif Hukum Islam}

Pola kemitraan peternakan ayam di Panca Rijang Sidrap merupakan kerjasama kemitraan antara dua pihak yaitu pihak PT. Ciomas Adisatwa selaku perusahaan inti bekerjasama atau bermitra dengan para peternak ayam yang berada di Panca Rijang Sidrap. Kerjasama ini dimaksudkan untuk saling menolong dan saling menguntungkan. Perjanjian Kemitraan pada peternak ayam potong di Panca Rijang Sidrap antara perusahaan PT.Ciomas Adisatwa tertuang dalam bentuk perjanjian tertulis dan dalam pelaksanaanya ada surat kesepakatan yang merupakan bagian yang tidak terpisahkan dari perjanjian.

Kontrak kerjasama yang telah terjalin antara peternak ayam potong di Panca Rijang Sidrap dengan PT.Ciomas Adisatwa merupakan jenis kontrak baku, diawal perjanjian seluruh isi kontrak (perjanjian) sudah ditetapkan oleh pihak perusahaan PT. Ciomas Adisatwa sedangkan pihak peternak ayam potong di 
Abdul Hamid dan Aris:

Analisis Hukum Islam Terhadap Pola Kemitraan Usaha Peternakan Ayam Potong di Panca Rijang Sidrap

Panca Rijang Sidrap sebagai serikat perusahaan hanya menyetujui dan menerima secara utuh isi perjanjian yang telah dibuat oleh pihak perusahaan. Dalam kontrak perjanjian tersebut pihak perusahaan yang bertindak sebagai inti menyediakan sarana produksi yang berupa bbit yam (DOC), pakan serta obat-obatan, adapun pihak peternak hanya mempersiapkan kandang serta pelaralatan yang digunakan berternak.

Syirkah dalam hukum Islam berarti berarti ikhtila $>$ th (percampuran), yaitu bercampurnya harta seseorang dengan harta orang lain hingga tidak dapat membedakan antara keduanya. Syirkah merupakan percampuran sehingga mengalami kesulitan untuk membedakannya. syirkah merupakan perserikatan dagang, sehingga dengan adanya akad syirkah tersebut yang telah disepakati oleh kedua belah pihak yang mengikatkan dirinya, maka keduanya memiliki hak bertindak hukum terhadap harta serikat tersebut serta berhak memperoleh keuntungan yang didasrkan pada persetujuan yang telah disepakati bersama. ${ }^{14}$ Kontrak kerjasama (syirkah) adalah transaksi yang diperbolehkan dalam syariat. Hal tersebut didasarkan pada Al-Quran, sunnah dan ijma, serta tidak menyalhi ketentua-ketentuan dan syarat-syarat yang telah ditetapkan baik dalam Al-Quran, sunnah maupun ijma. Hikmah pembolehan serikat ini adalah untuk memberikan kemudahan serta kelonggaran kepada umat dalam perekonomian mereka dengan cara mendapatkan keuntungan secara bersamasama tanpa adanya kerugian. ${ }^{15}$

Dalam Syirkah penting untuk diketahui dalam Islam karena banyak praktek kerjasama dalam model ini yakni kerjasama dalam bentuk investasi, perdagangan, pertanian dll. Sehingga terus berkembang dan terus dipraktekkan oleh orang-orang, ini merupakan salah satu saling tolong menolong untuk mendapatkan laba dengan mengembangkan dan menginvestasikan harta, serta saling menukar keahlian. Sebagaimana yang dinyatakan dalam QS. Al Maidah/5:2

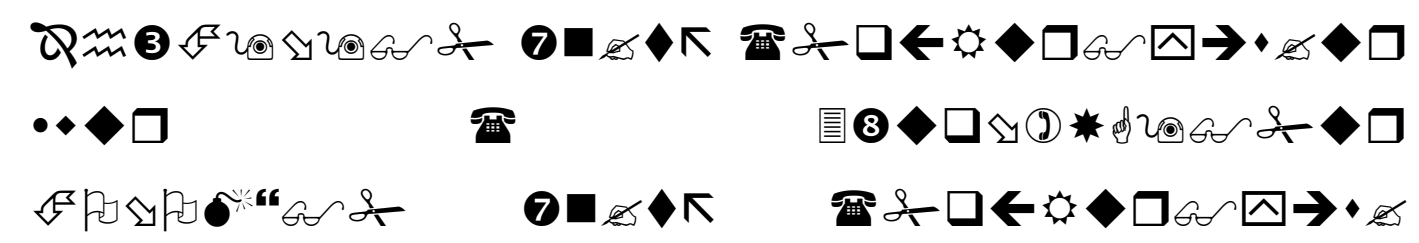




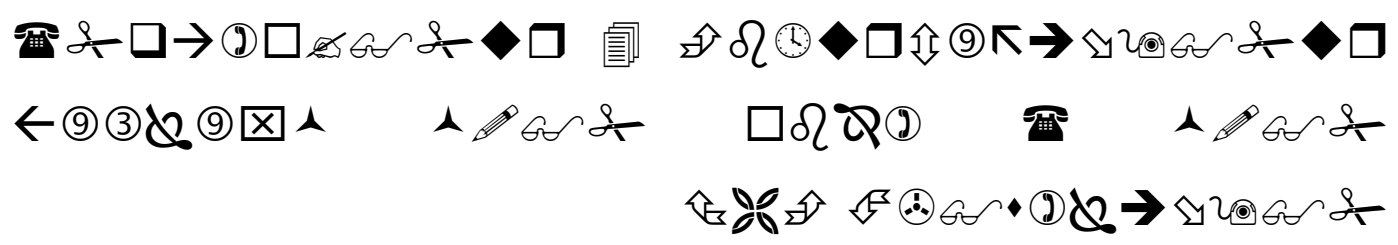

Terjemahnya:

dan tolong-menolonglah kamu dalam (mengerjakan) kebajikan dan takwa, dan jangan tolong-menolong dalam berbuat dosa dan pelanggaran. dan bertakwalah kamu kepada Allah, Sesungguhnya Allah amat berat siksaNya. ${ }^{16}$

Ayat tersebut menjelasakan bahwa tujuan dari kerjasama adalah saling tolong menolong serta diberikan berbagai kemudahan dalam kehidupan. Adanya kerjasama dalam Islam maka semua umat Islam akan senantiasa membiasakan diri untuk tolong menolong dalam hal apapun dalam kehidupan bermasyarakat yang mempunyai nilai positif untuk menuju kehidupan masyarakat yang lebih baik di masa mendatang. Agama Islam juga mewajibkan kepada seluruh umat untuk saling bekerjasama dan tolong menolong dalam kebaikan. Agama Islam juga mewajibkan umatnya untuk bekerja keras dalam mencari penghidupan agar dari waktu kewaktu kehidupannya menjadi lebih baik.

Siapapun diperbolehkan untuk berbisnis dalam Islam, akan tetapi dia tidak dibenarkan adanya ikhtikar, yaitu mengambil keuntungan di atas keuntungan normal dengan cara menjual lebih sedikit barang untuk harga yang lebih tinggi. Hal tersebut didasarkan pada hadis yang bersumber dari Muslim, Ahmad, Abu Daud dari Said bin al-Musyyab dari Ma'mar bin Abdullah Al-Adawi bahwasanya Rasululah saw bersabda: "Tidaklah orang yang melakukan ihktikar itu berdosa" Islam menghargai hak penjual dan hak pembeli untuk menentukan harga sekaligus melindungi hak-hak keduanya.. ${ }^{17}$

Berdasarkan penjelasan di atas diketahui bahwa antara peternak dan perusahaan keduanya ikut berpartisifasi dalam permodalan. Pihak peternak menyiapkan lahan serta pekerja sementara perusahaan berpartisipasi menyiapkan sarana produksi yaitu bibit ayam (DOC), pakan ternak serta obat-obatan. Dengan demikian bahwa akad yang dipergunakan oleh para pihak dalam transaksi tersebut adalah akad syirkah. Dalam kerjasama tersebut antara perusahaan dan peternak menggunakan akad syirkah yakni dalam cakupan syirkah 'inan yaitu persetujuan 
Abdul Hamid dan Aris:

Analisis Hukum Islam Terhadap Pola Kemitraan Usaha Peternakan Ayam Potong di Panca Rijang Sidrap

antara dua pihak atau lebih untuk masing-masing memasukkan bagian tertentu berupa modal yang akan diperdagangkan dengan ketentuan keuntungan dibagi antara para anggota sesuai yang telah disepakati bersama. Syirkah inan dilakukan dalam bentuk kerjasama modal serta kerjasama keahlian dan pekerjaan. Keuntungan maupun kerugian didasarkan atas kesepakatan keduan belah pihak. ${ }^{18}$

Selanjutnya, kerjasama kemitraan yang dilakukan oleh pihak perusahaan dan pihak peternak melalui penyertaan modal usaha dibolehkan dalam Islam, bahkan sangat dianjurkan sebagai landasan tolong-menolong terhadap sesama umat dengan tujuan saling membantu, saling membutuhkan dan saling menguntungkan. Kerjasama dalam Islam dilakukan dalam hal memperoleh harta dibolehkan selama tidak ada merugikan salah satu pihak karena kerjasama dalam Islam selalu bertujuan agar umat manusia saling tolong menolong dalam memperoleh harta yang halal dan baik. Ditinjau dari ekonomi Islam kerjasama ini merupakan kerangka muamalah Islam. Dan juga di dalam kerjasama usaha peternakan ini tidak boleh mengkhianati antara satu pihak dengan pihak lain, dan harus mentaati perjanjian yang telah disepakati setelah ditandatanganinya kontrak kesepakatan, sebagaimana firman Allah SWT:

Dalam Al Qur'an surah Al Maidah/5:1

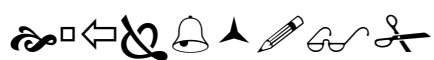

苗\&

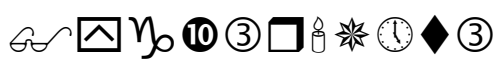

क्ष \&

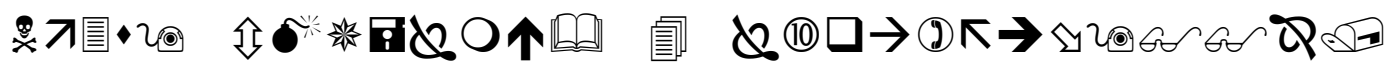

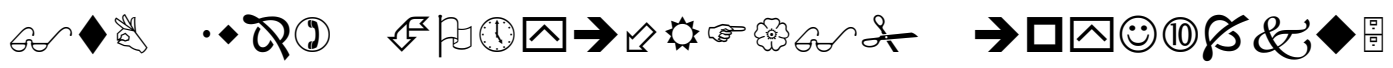
7)

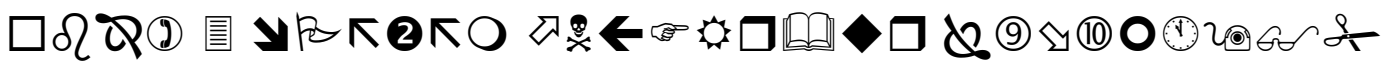

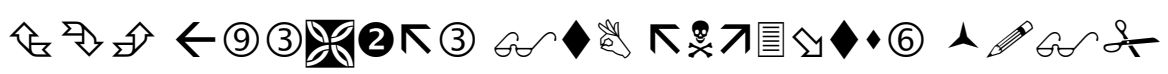
Terjemahnya:

Hai orang-orang yang beriman, penuhilah aqad-aqad itu. dihalalkan bagimu binatang ternak, kecuali yang akan dibacakan kepadamu. (yang demikian itu) dengan tidak menghalalkan berburu ketika kamu sedang mengerjakan haji. Sesungguhnya Allah menetapkan hukum-hukum menurut yang dikehendaki-Nya. ${ }^{19}$ 
Abdul Hamid dan Aris:

Analisis Hukum Islam Terhadap Pola Kemitraan Usaha Peternakan Ayam Potong di Panca Rijang Sidrap

Kerjasama sistem ini juga tidak dibenarkan untuk memakan harta dengan cara yang bathil tanpa kesepakatan terlebih dahulu sebagaimana firman Allah.

Dalam Al Qur'an surah An Nisa'/4:29.

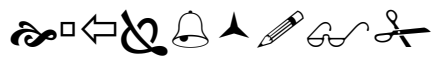

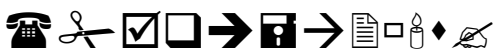

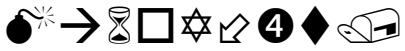

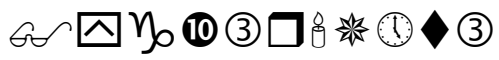

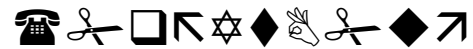

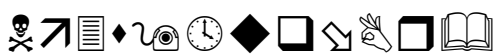

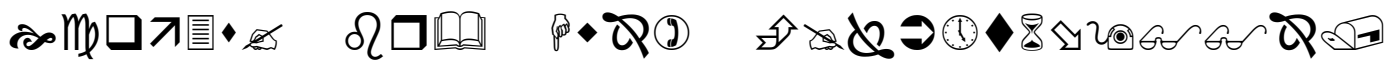

$\bullet \bullet \square$ 国

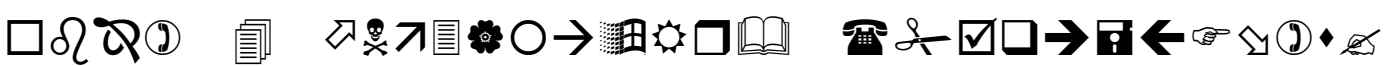

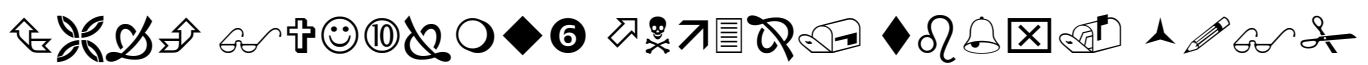

Terjemahnya:

Hai orang-orang yang beriman, janganlah kamu saling memakan harta sesamamu dengan jalan yang batil, kecuali dengan jalan perniagaan yang berlaku dengan suka sama-suka di antara kamu. dan janganlah kamu membunuh dirimu dan Sesungguhnya Allah adalah Maha Penyayang kepadamu. $^{20}$

Maksud dari ayat tersebut ditarik kesimpulan bahwa membuat kontrak perjanjian hukumnya selama tidak ada unsur penganiayaan berupa mengambil harta secara bathil ataukan bertentangan dengan ketentuan-ketentuan dalam al Qur'an.

Islam mendorong setiap pemeluknya untuk bekerja dan terus meningkatkan etos kerja dan profesionalisme serta kerjasama dimana modal atau tenaga dikombinasikan sehingga menghasilkan barang atau jasa yang diperlukan oleh umat manusia. Sistem ekonomi Islam itu berbeda dengan sistem ekonomi lain, kerjasama merupakan karakteristik yang melekat kuat dalam sistem ekonomi Islam, sekaligus membedakannya dengan sistem ekonomi lain. Nilai kerjasama dalam sistem ekonomi Islam tercermin pada semua tingkat kegiatan ekonomi, produksi, distribusi barang dan jasa.

Kehadiran manusia di muka bumi tidak terlepas dari tidak terlepaskan dari visi ekonomi dan bisnis. Manusia dihadirkan di muka bumi dimaksudkan sebagai penebar rahmat melalui serangkaian kegiatan ekonomi dan bisnis yang 
$\mathcal{A} 6$ du $\mathcal{H}$ Hamid dan Arís:

Analisis Hukum Islam Terhadap Pola Kemitraan Usaha Peternakan Ayam Potong di Panca Rijang Sidrap

dilakukannya

dengan tujuan akhir adalah ridha Allah SWT. ${ }^{21}$ Analisis ekonomi dalam hal ini dibutuhkan pada usaha peternakan ayam potong, dengan melakukan analisis ekonomi menjadikan lebih memahami prospek usaha peternakan ayam ke depannya. Analisis ekonomi juga dapat memprediksi seberapa lama sebuah usaha peternakan akan tetap mampu bertahan dan bersaing dalam persaingan bisnis yang semakin ketat dengan selalu melakukan perbaikan manajemen pemeliharaan.

Jadi kerjasama yang dilakukan antara perusahaan dan peternak pada dasarnya dibolehkan dalam Islam, karena dengan adanya kemitraan dan kerjasama dari perusahaan dan peternak. Oleh karena itu, kerjasama yang dilakukan berjalan sesuai dengan prinsip dan aturan Islam yang bertujuan untuk kemaslahatan dan mensejahterakan umat manusia. Namun, yang perlu diperbaiki dan diubah dari sistem kerjasama adalah prinsip kejujuran dan keterbukaan dari kedua belah pihak yang bekerjasama.

Bentuk kerjasama yang dilakukan oleh pihak perusahaan dan pihak peternak adalah dengan memberikan modal usaha dalam bentuk penyertaan. Dalam Islam, memberikan pinjaman kepada orang yang membutuhkan diperintahkan dalam Al-Qur'an. Islam menganjurkan untuk memilih kehidupan dunia yang berdemensi akhirat. Dengan pilihan ini, maka seseorang akan mendapat tidak hanya kebaikan dalam kehidupan dunia yang pasti akan menjadi kebahagian di akhirat kelak. Inilah arti dari bekerja itu ibadah, berdagang itu adalah ibadah dan tolong menolong terhadap sesama adalah ibadah dan seterusnya.

\section{PENUTUP}

Kerjasama kemitraan atau yang dikenal sebagai syirkah yaitu kerjasama antara dua pihak yakni antara pihak perusahaan (INTI) dengan pihak peternak (PLASMA). Pola kemitraan yang dilaksanakan oleh PT. Ciomas Adisatwa adalah pola INTI-PLASMA, yaitu pihak perusahaan bertindak sebagai inti menyediakan sarana produksi berupa DOC, pakan beserta obat-obatan sedangkan pihak 
Abdul Hamid dan Aris:

Analisis Hukum Islam Terhadap Pola Kemitraan Usaha Peternakan Ayam Potong di Panca Rijang Sidrap

peternak bertindak sebagai plasma menyediakan kandang serta peralatan kandang yang diperlukan. Yang berperan aktif dalam masa pemeliharaan usaha ternak ayam tersebut ialah pihak plasma beserta karyawan yang dipekerjakan. Hal-hal yang dilakukan dalam masa pemeliharaan ternak ayam potong tersebut mulai dari pemasukan bibit ayam (DOC), sampai dengan masa pemeliharaan yang terhitung selama 25 hari sampai 30 hari. Kemudian setelah dari pihak perusahaan menyatakan ayam tersebut sudah layak diperjualbelikan maka barulah dilakukan masa panen serta melakukan pembagian keuntungan dari pihak perusahaan.

Adapun tanggapan dalam masa pemeliharaan terhadap kerugian dalam sistem gagal panen. Dalam hal tersebut dari pihak peternak dapat mengalami kerugian terhadap tenaga dan biaya yang dikeluarkan seperti biaya listrik dsb.Menurut pandangan ekonomi Islam, kerjasama yang dilakukan oleh pihak perusahaan dan pihak peternak dibolehkan dalam Islam. Dan dianjurkan untuk saling tolong-menolong dalam kebaikan. Akan tetapi kerjasama tersebut harus dengan adanya saling membantu, saling membutuhkan dan saling menguntungkan antara sesama yang telah melakukan kerjasama.

\section{Catatan Akhir}

${ }^{1}$ Ahmad Sofyan, "Strategi Kemitraan dalam Saluran Distribusi untuk Menigkatkan Kinerja Bisnis" (Skripsi Pasca Sarjana Universitas Diponogoro: Semarang, 2006), h.1 http://AhmadSopyan.pdf(di akses pada tanggal 02 mei 2017).

${ }^{2}$ Kementerian Pertanian RI, Statistik Peternakan Dan Kesehatan Hewan, Direktorat Jenderal Peternakan dan Kesehatan Hewan, Jakarta:2013, h.18. http://1391361001-2-BAB 1 sidang.pdf (06Mei2017).

${ }^{3}$ Putria Fajri Ramadhani, Analisis Pendapatan Peternak Ayam Potong (Universitas Diponegoro:2014), h.8, Skripsi.http://eprints.undip.ac.id43003102_RAMADHANI.pdf (pada tanggal 02 Mei 2017).

${ }^{4}$ http://www.hestanto.web.id/teori-pola-kemitraan-menurut-para-ahli/(Diakes pada tgl 24 Agustus 2017).

${ }^{5}$ Mohammad Jafar Hafsah, Kemitraan Usaha (Jakarta: Sinar Harapan, 2000), h.10.

${ }^{6}$ Departemen Pendidikan Nasional, Kamus Besar Bahasa Indonesia, Edisi IV (Jakarta: PT Gramedia Pustaka Utama, 2008), h.1538.

${ }^{7}$ Jeane neltje saly, Usaha Kecil, Penanaman Modal Asing dalam Peresfektif Pandangan Internasional, (Jakarta: Badan Pembinaan Hukum Nasional, 2001), hal.35.

${ }^{8}$ Hendi Suhendi, Fiqih Muamalah (Jakarta: PT. Raja Gafindo Persada, 2007), hal.125. 
Abdul Hamid dan Aris:

Analisis Hukum Islam Terhadap Pola Kemitraan Usaha Peternakan Ayam Potong di Panca Rijang Sidrap

${ }^{9}$ Ascarya, Akad dan Produk Bank Syariah ( Jakarta: PT. Raja Grafindo Persada, 2007), h.146.

${ }^{10}$ Muhammad, Etika Bisnis Islam (Yogyakarta: Akademi Manajemen, 2002), h.79.

${ }^{11}$ Pak Iwan, Kepala Unit PT.Ciomas Adisatwa Sidrap, wawancara oleh peneliti di Kantor PT.Ciomas Adisatwa, 24 November 2017.

${ }^{12}$ Pak Iwan, Kepala Unit PT.Ciomas Adisatwa Sidrap, wawancara oleh peneliti di Kantor PT.Ciomas Adisatwa, 24 November 2017

${ }^{13}$ Pak Iwan, wawancara oleh peneliti di Kantor PT.Ciomas Adisatwa, 24 November 2017.

${ }^{14}$ Adbul Azis Dahlan, Ensiklopedia Hukum Islam (Jakarta: Ichtiar Baru Van Hoever, 2003),

h. 1711 .

${ }^{15}$ Amir Syarifuddin, Garis-garis Besar Fiqh (Bogor: Kencana, 2003), h. 217.

${ }^{16}$ Departemen Agama Republik Indonesia, Al Quran dan Terjemahanya (Bandung: PT.Syamsil Cipta Media, 2005), h.156.

${ }^{17}$ Adiwarman A. karim, Ekonomi Mikro Islami (Jakarta: PT. Raja Grafindo Persada, 2007), h. 132.

${ }^{18}$ PPHIMM, Kompilasi Hukum Ekonomi Syariah (Jakarta: Kencana, 2009), h.52.

${ }^{19}$ Departemen Agama Republik Indonesia, Al Quran dan Terjemahanya (Bandung: PT.Syamsil Cipta Media, 2005), h.156.

${ }^{20}$ Departemen Agama Republik Indonesia, Al Quran dan Terjemahanya (Bandung: PT.Syamsil Cipta Media, 2005), h.122.

${ }^{21}$ Muhammad, Prinsip-Prinsip Ekonomi Islam (Graha Ilmu:Yogyakarta, 2007), h. 61.

\section{DAFTAR PUSTAKA}

Ahmad Sofyan, "Strategi Kemitraan dalam Saluran Distribusi untuk Menigkatkan Kinerja Bisnis" (Skripsi Pasca Sarjana Universitas Diponogoro: Semarang, 2006), h.1 http://AhmadSopyan.pdf(di akses pada tanggal 02 mei 2017).

Anwar ,Syamsul. 2007. Hukum Perjanjian Islam, Ed. 1, Jakarta: PT Raja Grafindo Persada.

Ascarya. 2007. Akaddan Produk Bank Syariah. Jakarta: PT. Raja Grafindo Persada.

Azis Adbul Dahlan. 2003. Ensiklopedia Hukum Islam, Jakarta: Ichtiar Baru Van Hoever.

Departemen Agama Republik Indonesia. 2005. Al Quran dan Terjemahanya, Bandung: PT.Syamsil Cipta Media. 
AbduC Hamid dan Aris:

Analisis Hukum Islam Terhadap Pola Kemitraan Usaha Peternakan Ayam Potong di Panca Rijang Sidrap

Departemen Pendidikan Nasional. 2008. Kamus Besar Bahasa Indonesia, Edisi IV, Jakarta: PT Gramedia Pustaka Utama.

Dewi ,Gemaladkk. 2006. Aspek-aspek Hukum dalam Perbankan dan Perasuransian Syariah di Indonesia, Edisi Revisi, Jakarta: KencanaPrenada Media Group.

Edwin, Mustafa Nasution. 2007. Pengenalan Ekluasif Ekonomi Islam, Cet. II;Jakarta: Kencana Prenada Media Grop.

Eko Srimindarto, "Perjanjian Kemitraan dengan Pola Inti Plasma Pada Peternakan Ayam Broiler di Pemerintah Kabupaten Grobongan Jawa Tengah". Skripsi http://digilib. Uinsby.ac.id/3041411027.pdf (Diakses pada tanggal 06 Januari 2018).

Ekonomi Islam. 2008. Pusat Pengajian danPengembangan Ekonomi Islam (P3EI) Universitas Islam Indonesia Yogykarta atas kerjasma dengan Bnak Indonesia, Jakarta: PT. Raja GarPfindo Persada.

Handy Putra Utama, Analisis Hukum Islam terhadap Pola Kemitraan dalam usaha Peternakan Ayam Broiler di PT Kenongo Perdana Pasuruan,Skripsi http://digilib. Uinsby. ac.id/3984/5/BAB\%202.pdf (Diakses pada tanggal 07 September 2017).

Hasnih, Analisis Tingkat Kepuasan Peternak Broiler dengan Pola Kemitraan Terhadap Kinerja PT Srikandi Agung Makassar (Study Kasus Kabupaten Maros),Skripsi http://digilib.uinsby.ac.id/3984/5/BAB\%202.pdf (Diakses pada tanggal 17 Oktober 2017).

http://2013-1-54201-614409024-bab4-31072013084436.pdf (2 juni 2017).

http://www.hestanto.web.id/teori-pola-kemitraan-menurut-para-ahli/(Diakes padatgl 24 Agustus 2017).

http://www.landasanteori.com/2015/09/pengertian-kontrak-definisi-menurut kuh.html (Diaksesepadatanggal 25 Meret 2018).

Jafar Mohammad Hafsah. 2000. Kemitraan Usaha, Jakarta: Sina rHarapan.

Karim, Adiwarman A. 2002. Ekonomi Islam Suatu Kajian Konterporer, Jakarta: PT. Gema Insani.

Karim, Adiwarman A. 2007. Ekonomi Mikro Islami, Jakarta: PT. Raja Grafindo Persada. 
Abdul Hamid dan Aris:

Analisis Hukum Islam Terhadap Pola Kemitraan Usaha Peternakan Ayam Potong di Panca Rijang Sidrap

Kementerian Pertanian RI ,Statistik Peternakan Dan Kesehatan Hewan, Direktorat Jenderal Peternakan dan Kesehatan Hewan, Jakarta:2013, h.18. http://1391361001-2-BAB 1 sidang.pdf (06Mei2017).

Lubis, Suhrawardi K. 2012. Hukum Ekonomi Islam, Jakarta: Sinar Grafika.

M. Dwi Budi Hariyanto, "Perjanjian Kemitraan dengan pola inti plasma pada peternak ayam broiler di Desa Turi Toyaning Kecamatan Rejoso Kabupaten Pasuruan (Tinjauan Kompilasi Hukum Ekonomi Syariah)"..Skripsi http:// 10220057_Pendahuluan.pdf (Diakses pada tanggal 27 Maret 2018).

Manan, Abdul. 2014. Hukum Ekonomi Syariah dalam Perspektif Kewenangan Peradilan Agama, Cet.II; Jakarta: Prenada media.

Muhammad. 2002. Etika Bisnis Islam, Yogyakarta: Akademi Manajemen.

Muhammad. 2007.Prinsip-Prinsip Ekonomi Islam, Graha Ilmu:Yogyakarta.

Neltje Jeane saly. 2001. Usaha Kecil, Penanaman Modal Asing dalam Peresfektif Pandangan Internasional, Jakarta: Badan Pembinaan Hukum Nasional.

Pasaribu, Chairuman Suhrawardi. 1994. Hukum Perjanjian Dalam Islam, Jakarta: Sinar Grafika.

Pasaribu, Chairuman Suhrawardi. 2004. Hukum Perjanjian Dalam Islam, Jakarta: Sinar Grafika.

PPHIMM. 2009. Kompilasi Hukum Ekonomi Syariah, Jakarta: Kencana.

Pusat Pengkajian dan Pengembangan Ekonomi Islam Indonesia Yokyakarta atas Kerja Sama dengan Bank Indonesia. 2012. Ekonomi Islam, Cet,IV; Jakarta: PT Raja Grafindo Persada.

Pusat Pengkajian Hukum Islam dan Masyarakat Madani. 2009. Kompilasi Hukum Ekonomi Syariah, Jakarta: Kencana.

Putria Fajri Ramadhani, Analisis Pendapatan Peternak Ayam Potong (Universitas Diponegoro:2014), h.8, Skripsi http://eprints.undip.ac.id 43003102_ RAMADHANI.pdf (pada tanggal 02 Mei 2017).

R, Fadillah. 2004. Kunci Sukses Berternak Ayam Broiler di Daerah Tropis, Jakarta: Agromedia Pustaka.

Rasyid, Harun. 2000. Metode Penelitian Kualitatif Bidang Ilmu Sosial Agama, Pontianak: STAIN Pontianak. 
Abdul Hamid dan Aris:

Analisis Hukum Islam Terhadap Pola Kemitraan Usaha Peternakan Ayam Potong di Panca Rijang Sidrap

Rianto, Nur Al Arif, EuisAmalia. 2014. Teori Mikro Ekonomi Suatu Perbandingan Ekonomi Islam dan Ekonomi Konvensional, Cet:2; Jakarta: Kencana.

Rivai Veithzal,Andi Buchari. 2009. Islamic Economics Ekonomi Syariah. Jakarta: PT Bumi Aksara.

Salim H.S. 2004. "Hukum Kontrak: Teori \& Teknik Penyusunan Kontrak," Cet. II, Jakarta: Sinar Grafika.

Subekti R, R Tjipto. 2001. KUHPerdata, Jakarta: Pradya Paramita.

Suhendi Hendi. 2007. Fiqih Muamalah, Jakarta: PT. Raja Gafindo Persada.

Suhrawardi K, Lubus. 2014. Hukum Ekonomi Islam, Ed. 1, Cet.2; Jakarta: Sinar Grafika.

Sukirno, Sadono. 2012. Mikro Ekoomi Teori Pengantar, Cet.27; Jakarta: PT Raja Grafindo Persada.

Syafei, Rahmat. 2006. Fikih Muamalah untuk UIN, STAIN, PTAIS dan Umum, Bandung: Pustaka Setia.

Syarifuddin Amir.2003.Garis-garis Besar Fiqh, Bogor: Kencana.

Tim Pustaka Phoenix. 2010. Kamus Besar Bahasa Indonesia Edisi Baru, Jakarta: Media Pustaka Phoenix.

Yunia Ika Fuzia. 2014. Prinsip Dasar Ekonomi Islam Presfektif Maqashid alSyariah, Jakarta: PT.Adhitya Agung. 